УДК 343.23:001.8 (477)

DOI https://doi.org/10.32837/pyuv.v2i3(28).381

\author{
І. Ю. Щербініна \\ аспірант кафедри крилінального права № 2 \\ Національного юридичного університету ілені Ярослава Мудрого
}

\title{
НАУКОВІ ПІДХОДИ ДО РОЗУМІННЯ ОБ'СКТА ЗЛОЧИНУ КРІЗЬ ПРИЗМУ ЗАПОДІЯННЯ ЙОМУ ШКОДИ
}

Протягом століть злочином уважалося все, що може завдати шкоди правителю, безпосередньо особі, релігії, суспільному благу й іншим цінностям. Саме шкода (яка полягає насамперед у суспільно небезпечних наслідках злочину) $€$ найважливішим показником суспільної небезпечності злочину та слугує основним вираженням їі сутності. Вона іманентно притаманна всім без винятку злочинам, а її розмір істотно відрізняється від розміру шкоди, якої завдають інші правопорушення. Справді, шкода є основним, головним, проте не єдиним проявом суспільної небезпечності, адже на ступінь і характер цієї матеріальної ознаки злочину впливають ще й інші об’єктивні та суб’єктивні ознаки. Крім того, шкоду, завдану внаслідок учинення суспільно небезпечного діяння, неможливо розглядати ізольовано від об'єкта злочину, адже суспільно небезпечні наслідки й об'єкт злочину тісно пов'язані одне з одним. Цей зв'язок проявляється в певному впливі суспільно небезпечного діяння на конкретний об’єкт злочину, унаслідок чого йому завдано шкоди.

Проблеми розуміння об'єкта злочину досліджували такі відомі вчені-криміналісти, як: В.К. Глістін, В.Я. Тацій, М.С. Таганцев, А.Н. Трайнін, В.М. Кудрявцев, В.В. Мальцев, Б.С. Нікіфоров, А.А. Піонтковський, В.Д. Спасович, М.Д. Сергєєвський, А.В. Наумов та інші.

Мета статті - дослідити основні концепції розуміння об'єкта злочину, а також виокремити теорії, у межах яких буде розглянута проблема механізму завдання йому шкоди.

Вчення про об'єкт є одним із фундаментальних, важливих і водночас найскладніших і найбільш контраверсійних у науці кримінального права. Напевно, немає в теорії кримінального права іншого такого питання, щодо якого існує безліч різних, а в деяких випадках і прямо протилежних позицій, як стосовно питань, пов'язаних із проблемою об'єкта злочину.

Кримінальне право більшості іноземних країн не надає великого значення поняттю об’єкта злочину. Річ у тому, що більшість закордонних кримінальних кодексів використовують формальне визначення злочину (діяння, передбачене кримінальним законом під загрозою покарання). На наш погляд, це пов'язано не з тим, що закордонна наука кримінального права (особливо за- хідна) відкидає ознаку суспільної небезпечності, а $з$ тим, що в цих країнах існують певні законодавчі традиції. Так, наприклад, у законодавстві Німеччини визначення злочину з'явилося під час активного розвитку класичної школи кримінального права, коли поняття суспільної небезпечності та матеріального визначення злочину ще не існувало навіть у зародку.

Погоджуючись із думкою, що «жодна 3 концепцій об'єкта злочину <...> не може вважатися єдино правильною <...>, кожна 3 них має право на існування, оскільки має як позитивні, об'єктивно беззаперечні моменти, так і спірні або неприйнятні моменти, передусім із методологічного погляду» [1, с. 8], уважаємо, що вибір, зроблений на підтримку тієї чи іншої концепції, не може бути інтуїтивним або політично «забарвленим». Такий вибір має бути насамперед обгрунтованим і зумовленим потребою дослідження конкретного соціально-правового явища. Обгрунтування вибору концепції об’єкта злочину має бути дуже ретельним, послідовним і підкріпленим вагомими аргументами. Що ми і спробуємо зробити надалі.

Еволюція поглядів на об'єкт злочину неодмінно впливає на зміну поглядів щодо розуміння поняття злочину. У період, коли об'єктом злочину визначалися закон, норма права чи заборона, єдиною ознакою, що лежала в основі поняття злочину, була ознака протиправності як вираження принципу “nullum crimen sine lege”. Проте об’єктом злочину може бути визнано лише те, що потерпає від шкоди внаслідок злочину. У зв'язку із цим не є об'єктом злочину самі закони, кримінально-правові норми чи заборони, адже вони не зазнають шкоди від злочину. Отже, головною проблемою цих теорій є те, що вони не розкривають реальну соціальну сутність злочину - його суспільну небезпечність, а тому задовільними в рамках розгляду проблеми суспільно небезпечних наслідків уважатися не можуть.

Цікавою є концепція «злочин як порушення права», висунута В.Д. Спасовичем ще у XIX ст., яка і дотепер знаходить своїх прихильників серед сучасних учених-криміналістів. На думку автора, «преступление есть противозаконное посягательство на чье-либо право, столь существенное, что государство, считая это право одним из необходимых условий общежития, при недостаточности 
других средств охранительных, ограждает ненарушимость его наказанием» [6, с. 84].

Як видно, згадана концепція зводить злочин до порушення прав громадянина або прав держави, водночас права, що порушуються, мають бути суттєвими та важливими для суспільства. Критикуючи таку позицію, М.С. Таганцев зазначав: «Посягательство на субъективное право составляет не сущность, а только средство, путём которого виновный посягает на норму права, на которой покоится субъективное право <...>. Право в субъективном смысле, в свою очередь, представляет собой отвлеченное понятие, как и норма, а потому само по себе, по общему правилу, не может быть непосредственным объектом преступного посягательства, пока оно не найдет выражения в конкретно существующем благе или интересе <...> Для преступного посягательства на такое право $<. .>$ необходимо посягательство на проявление этого права» [7, с. 31-32]. Тобто недолік цього погляду полягає в тому, що об'єкт злочину визначається занадто абстрактно, через що унеможливлюється встановлення рівня шкоди, завданого внаслідок учинення злочину.

У межах нормативної концепції розвивав свої ідеї і М.С. Таганцев, учення про злочин якого можна назвати концепцією життєвого інтересу [2, с. 11]. Автор зазначав: «Посягательство на норму права в её реальном бытии есть посягательство на правоохраненный интерес жизни, на правовое благо» [7, с. 32]. Такими інтересами можуть бути: особистість та їі блага - життя, тілесна недоторканність, особисті думки, честь, володіння або користування відомими предметами зовнішнього світу; прояв особистості ззовні, свобода пересування і діяльності в її різних сферах тощо. М.С. Таганцев зазначав, що охорона регульованого нормою права життєвого інтересу не полягає суто в тому, щоб убезпечити інтерес від шкоди, хоча шкода інтересу і є важливою складовою частиною віднесення діяння до розряду злочинних [7, с. 35]. Окрім спричинення шкоди, для визнання діяння злочинним необхідно, щоб цінність або інтерес мали властивість істотності [7, с. 34]. Проте, як зазначав і сам науковець, перелік і конкретний зміст тих цінностей суспільства, які охороняються кримінальним законом, змінюються із часом і залежать від діючих у конкретний історичний період соціально-економічних умов. А тому назвати в контексті цієї теорії суспільну небезпечність діяння константою злочину не уявляється можливим.

Різновидом концепції життєвого інтересу є теорія правового блага, у центрі якої - людина, адже саме їй, на думку авторів, насамперед завдають шкоди. Прибічник цієї теорії М.Д. Сергєєвський зазначав: «Вред, заключающийся в преступном деянии, может быть или вредом отдельному лицу, или вредом для всего общества, так как всякая норма, нарушенная преступным деянием, имеет своим предметом или права, блага и интересы частного лица, или интересы целого общества, или то и другое вместе» [5, с. 51].

Подібної позиції дотримуються і сучасні науковці. Наприклад, на думку авторів одного з підручників із Загальної частини кримінального права, «объект преступления - тот, против кого оно совершается, то есть отдельные лица или какое-то множество лиц, материальные или нематериальные ценности которых, будучи поставленными под уголовно-правовую охрану, подвергаются преступному воздействию, в результате чего этим лицам причиняется вред или создается угроза причинения вреда» [11, с. 135].

Останнім часом усе більше вчених-юристів пропонують повернутися до цих концепцій, в основі яких лежить розуміння об'єкта злочину як охоронюваних кримінальним законом цінностей, інтересів і благ. Водночас зазначені категорії часто розцінюються вченими як пов'язані одна з одною та ставляться в один ряд.

Так, за словами А.В. Наумова, «уявляється можливим повернення до теорії об'єкта як правового блага, створеної ще наприкінці минулого століття в рамках класичної і соціологічної шкіл кримінального права» [3, с. 92]. Аргументуючи таку позицію, більшість учених спираються на наукові досягнення М.С. Таганцева, про які йшлося вище. Окрім того, у процесі обгрунтування зазначеного погляду на об'єкт злочину більшість науковців також критикують теорію «об'єкт - суспільні відносини», водночас неодмінно підкреслюють політичну «забарвленість» i принижену абсолютну цінність людини як біологічної істоти, наголошують на неспроможності цієї концепції бути обраною за основу розуміння об'єкта злочину. Так, А.А. Тер-Акопов щодо цього писав: «Визнавати за сутність убивства порушення порядку відносин, які охороняють життя людини, - значить переставляти цінності з ніг на голову: визнавати основною соціальною цінністю не життя людини, а суспільні відносини, у які вона входить і які існують, власне, заради неї» [10, с. 10].

Справді, блага, цінності й інтереси є беззаперечно важливими для встановлення об'єкта злочину. Так, у ч. 1 ст. 1 Кримінального кодексу України зазначено, що цей Кодекс має своїм завданням правове забезпечення охорони прав $\mathrm{i}$ свобод людини і громадянина, власності, громадського порядку та громадської безпеки, довкілля, конституційного устрою України від злочинних посягань, гарантування миру і безпеки людства, а також запобігання злочинам.

Проте, на нашу думку, незважаючи на важливість зазначених цінностей, не можна ототожнювати їх з об'єктом злочину. По-перше, це пов'язано з тим, що не в усіх злочинах законодавець 
ставить під захист саме благо або інтерес. Так, наприклад, у злочинах у сфері службової діяльності важко встановити, якому саме благу або інтересу завдано шкоди, тому в цих злочинах об’єктом визнаються саме суспільні відносини, що визначають і регулюють зміст правильної роботи державного і громадського апарату.

По-друге, цінності, інтереси та блага, на нашу думку, виступають не стільки об'єктом, скільки певними «маркерами», орієнтирами, які допомагають цей об'єкт встановити. Наприклад, для розуміння об'єкта злочинів у сфері господарської діяльності, для встановлення суспільних відносин, що зазнають шкоди, важливо встановити той суспільний інтерес, який лежить в основі цих відносин. «Визначення об'єкта таких злочинів через інтерес є найбільш правильним і точним по суті, бо тільки інтерес наділений можливістю настільки повно і всебічно відображати зовні відповідне суспільне ставлення. Але водночас не можна забувати про умовність такого вирішення питання. Коли ми визначаємо об'єкт за допомогою вказівки на відповідний інтерес, то тим самим не підміняємо суспільні відносини як об'єкт злочину його інтересом» [8, с. 77].

По-третє, загальновідомо, що злочини вчиняються не тільки щодо чи у зв'язку з існуванням благ та цінностей як певних позитивних соціальних орієнтирів, а і в деяких випадках щодо явищ iз певними негативними властивостями, так званих «антиблаг», «антицінностей», наприклад, це можуть бути зброя, вибухові речовини, наркотичні засоби тощо [4, с. 70].

Крім того, вищезазначена концепція має ще один суттєвий недолік. Він полягає в тому, що така теорія занадто абстрактна, так би мовити, «аморфна». Істотність шкоди, важливість охоронюваних інтересів не мають чітких критеріїв і не дозволяють у зв'язку із цим відокремлювати злочинне від незлочинного.

Отже, цінності, блага, інтереси з вищезазначених причин, на нашу думку, не можуть бути визнані об'єктом злочину, проте ці соціальні орієнтири допомагають розкрити сутність і зміст суспільних відносин, вказати на важливість або необхідність їх кримінально-правової охорони.

Нагадаємо, що донедавна у вітчизняній науці кримінального права найпоширенішою була позиція, відповідно до якої об’єктом злочину одностайно визнавалися суспільні відносини, проте в останні роки вона все частіше стала піддаватися критиці. Більшість учених, що відхиляють цю концепцію, уважають їі пережитком минулого або штучно створеним постулатом радянських часів, який, на їхню думку, зневажає абсолютну цінність людини, перетворюючи їі на звичайного носія суспільних відносин. Утім, погоджуючись із думкою В.Я. Тація, уважаємо, що категорія «су- спільні відносини», якою охоплюються відносини між людьми, що існують у суспільстві та регулюються різноманітними соціальними нормами, є філософською (або соціологічною) і безпосередньо не стосується якогось історичного періоду $[9$, c. 131$]$.

У зв'язку із цим найбільш обгрунтованою серед теорій об'єкта вважаємо саме теорію суспільних відносин. Однак визнання цієї концепції зовсім не означає, що треба відмовитися від таких категорій, як «цінність», «інтерес», «благо». Навпаки, саме вони об'єктивізують суспільні відносини, у яких проявляється їхня соціальна сутність і цінність для суспільства.

Отже, саме суспільні відносини повинні визнаватися об’єктом злочину. Передусім це пов' язано з тим, що таке розуміння об'єкта надає можливість встановити характер і обсяг шкоди, що завдається правоохоронюваним відносинам, отже, встановити суспільну небезпечність злочину. Водночас встановлення характеру й обсягу шкоди тісно пов' язане зі структурою суспільних відносин. Загальновизнана триелементна структура суспільних відносин, яка складається з носіїв (суб'єктів) відносин, предмета, щодо якого існують відносини, та соціального зв'язку як змісту відносин. Існують також інші підходи до визначення структури суспільних відносин, але все ж таки більш обгрунтованою та повною є саме вищезазначена структура, адже включення до неї будь-яких інших, органічно не властивих суспільним відносинам елементів (наприклад, зовнішніх умов їх виникнення, передумов їх нормального функціонування, соціальних потреб та інтересів тощо) веде до того, що відносини як такі зникають і підміняються якимись іншими, більш загальними поняттями. Аналогічний негативний результат ми отримуємо і тоді, коли зі структури суспільних відносин необгрунтовано вилучається будь-який її обов'язковий елемент [8, с. 17].

Крім того, така структура дозволяе з'ясувати механізм завдання шкоди об'єкту кримінально-правової охорони. Розглядаючи структуру суспільних відносин, зазначимо, що остання являє собою не просто механічну сукупність певних частин, а цілісну систему відповідним чином взаємопов'язаних і взаємодіючих один з одним елементів. Це свідчить про те, що тільки суспільні відносини як цілісну систему, а не окрему її складову частину, можна визнати об'єктом злочину.

У разі вчинення будь-якого злочину вчиняється посягання на той чи інший структурний елемент суспільних відносин. Наприклад, у разі посягання на предмет суспільних відносин йому завдають шкоди шляхом знищення, пошкодження, модифікації, заміни або вилучення предмета зі структури суспільних відносин. В інших випадках предмет суспільних відносин може не підда- 
ватися безпосередньому злочинному впливу, водночас шкода суспільним відносинам завдається шляхом безпосереднього посягання на суб'єктів (учасників) відносин або на соціальний зв'язок між ними. Так, більшість злочинів проти життя і здоров'я вчиняються шляхом завдання шкоди суб'єктам (учасникам) охоронюваних суспільних відносин. Водночас такий злочин, як завдання майнової шкоди шляхом обману або зловживання довірою, шкодить об'єкту шляхом посягання на соціальний зв'язок охоронюваних відносин (у такому разі шкоди об'єкту завдають шляхом розриву соціального зв'язку).

Отже, встановлення об'єкта злочину - одне 3 важливіших питань у дослідженні суспільно небезпечних наслідків злочину та з'ясування механізму завдання шкоди суспільним відносинам, а також установлення суспільної небезпечності злочину. Шкода, завдана злочином, наповнює об'єкт, так би мовити, новим, модифікованим змістом або руйнує (знищує) його, що здебільшого і слугує основою для встановлення суспільної небезпечності злочину.

\section{Jimepamypa}

1. Гавриш С.Б. Теоретические предпосылки исследования объекта преступлений. Право и политика. 2000. № 11. С. 4-15.

2. Иванов Н.Г. Общественная опасность деяния как онтологическая основа криминализации : монография. Москва : Проспект, 2016.80 с.

3. Наумов А.В. Российское уголовное право. Общая часть : курс лекцій. Москва : БЕК, 1996. 560 с.

4. Основи кваліфікації злочинів : навчальний посібник / ред. М.І. Панов. Харків : Право, 2019. 378 с.

5. Сергеевский Н.Д. Русское уголовное право. Часть общая : пособие к лекциям. Санкт-Петербург, 1908. $385 \mathrm{c}$.

6. Спасович В.Д. Учебник уголовного права. Часть общая. Санкт-Петербург, 1863. 442 с.

7. Таганцев Н.С. Русское уголовное право. Часть общая : лекции : в 2-х т. Москва, 1994. Т. 1.380 с.

8. Таций В.Я. Объект и предмет преступления в советском уголовном праве : монография. Харьков : Вища школа, 1988. $198 \mathrm{c.}$

9. Тацій В.Я. Об'єкт злочину. Вісник асоціацї̈ кримінального права України. 2013. № 1. С. 131-134.

10. Тер-Акопов А.А. Ответственность за нарушение специальных правил поведения. Москва : Юридическая литература, 1995. $176 \mathrm{c.}$

11. Уголовное право. Общая часть : учебник / отв. ред. : И.Я. Козаченко, З.А. Незнамова. Москва : Норма-Инфра, 1999.516 с.

\section{Анотація}

Щербініна I. Ю. Наукові підходи до розуміння об'єкта злочину крізь призму заподіяння йому шкоди. - Стаття.

Стаття присвячена дослідженню проблеми розуміння об'єкта злочину у кримінальному праві та механізму завдання шкоди об'єкту злочину. Розглянуті основні наукові концепції вчених-криміналістів щодо розуміння об'єкта злочину у кримінальному праві. Встановлено, що проблема розуміння об’єкта злочину
$€$ однією з найважливіших і водночас найскладніших у науці кримінального права, а тому вибір, зроблений на підтримку того чи іншого підходу до розуміння об'єкта злочину, не може бути інтуїтивним або політично «забарвленим». Такий вибір має бути насамперед ретельно обгрунтованим, підкріпленим вагомими аргументами і зумовленим потребою дослідження конкретного соціально-правового явища. Останнім часом все більше вчених-юристів пропонують повернутися до концепцій, в основі яких лежить розуміння об'єкта злочину як охоронюваних кримінальним законом цінностей, інтересів і благ, проте, незважаючи на важливість зазначених цінностей, ототожнювати їх з об'єктом злочину не зовсім коректно у зв'язку з тим, що не в усіх злочинах законодавець ставить під охорону саме благо або інтерес (наприклад, злочини у сфері службової діяльності). Крім цього, злочини вчиняються не тільки стосовно чи у зв'язку з існуванням благ i цінностей, а і в деяких випадках стосовно явищ із певними негативними властивостями, так званих «антиблаг», «антицінностей». Найбільш обгрунтованою серед теорій розуміння об'єкта злочину крізь призму завдання йому шкоди варто вважати теорію суспільних відносин, адже таке розуміння об'єкта злочину надає можливість встановити характер і обсяг шкоди, що завдається правоохоронюваним відносинам, отже, визначити суспільну небезпечність злочину. Водночас характер і обсяг завданої шкоди тісно пов'язані зі структурою суспільних відносин. Саме триелементна структура суспільних відносин, яка складається з носіїв (суб'єктів) відносин, предмета, щодо якого існують відносини, та соціального зв'язку як змісту відносин, допомагає встановити механізм завдання шкоди об' $€$ ту кримінально-правової охорони, адже під час учинення злочинів завжди відбувається посягання на той чи інший структурний елемент суспільних відносин.

Ключові слова: злочин, об'єкт злочину, механізм завдання шкоди, суспільно небезпечні наслідки, шкода.

\section{Summary}

Shcherbinina I. Yu. Scientific approaches towards understanding the object of the crime through the prism of inflicting damage thereon. - Article.

The article is dedicated to the research on the problem of understanding the object of the crime in criminal law and the mechanism of inflicting damage on the object of the crime. Major scientific concepts of scientists-criminalists as to understanding the object of the crime in criminal law were analyzed. It was established that the problem of understanding the object of the crime is one of the most important and difficult at the same time within the context of criminal law science. That is why the choice made for the sake of one or other approach towards understanding the object of crime cannot be driven by intuition or political concerns. This choice has to be first of all thoroughly reasoned, backed by significant arguments and driven by the need to examine particular socio-legal phenomenon. Recently, more and more scientists-lawyers have argued for returning to perception of the object of the crime as values, interests and benefits protected by criminal law. However, notwithstanding the importance of the above-mentioned values, it is not quite accurate to equate them with the object of the crime. The reason for this lies in the fact that not in all crimes the legislator aims at protecting exactly benefits or interests (for example, crimes in the sphere of public service). Besides, the crimes are committed not only regarding or in view of benefits and values but also in particular cases regarding certain phenomena with neg- 
ative character, the so-called "anti-benefits", "anti-values". The most well-grounded amongst the theories of understanding the object of the crime through the prism of inflicting injury thereto is considered to be the theory of social relations, as such understanding of the object of the crime gives the opportunity to determine character and extent of harm which is inflicted on relations guarded by law, and, accordingly, determine the social danger of crime. Having said that, the character and extent of inflicted damage are tightly connected with the struc- ture of social relations. The three-element structure of social relations consists of relations carriers (subjects), the object of existing relations and social connections as the content of such relations. It helps to determine the mechanism of inflicting damage on the object of criminal protection, as commitment of crime always infringes one or other structural element of social relations.

Key words: crime, object of crime, mechanism of inflicting damage, socially dangerous consequences, harm. 